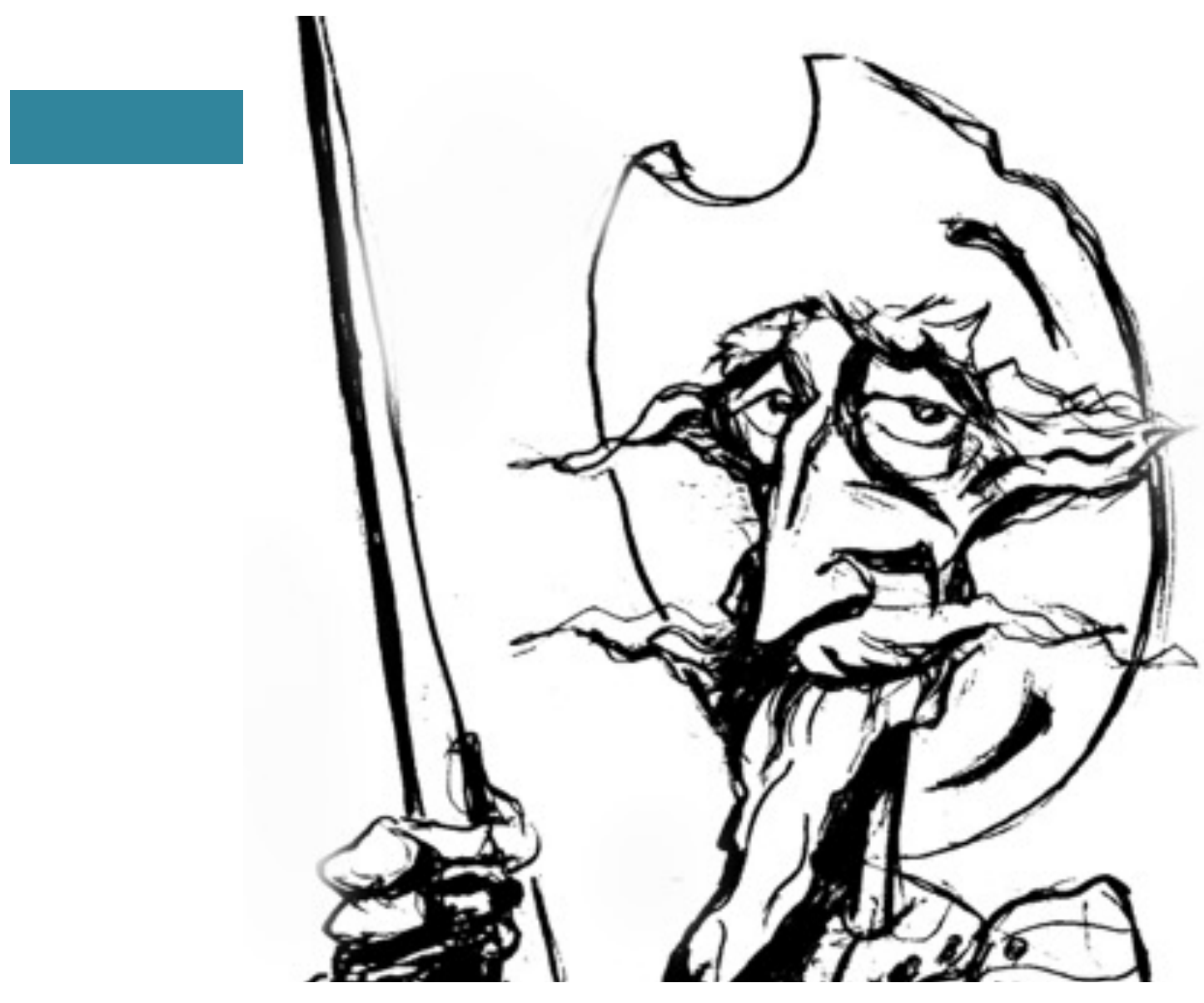

Hacia una historia crítica de la mirada.

Repensando el uso de la imagen dentro de las ciencias sociales

[Fabiola Flores Nava] 


\title{
Hacia una historia crítica de la mirada. Repensando el uso de la imagen dentro de las ciencias sociales
}

Towards a Critical History of the Gaze. Rethinking the Use of the Image within the Social Sciences

\author{
FABIOLA JESAVEL FLORES NAVA
}

\section{Resumen}

En este artículo, se rescata el discurso crítico como elemento fundamental para sustentar lo que se ha denominado Historia crítica de la mirada. Aquí no se intenta establecer un simple método de interpretación de la imagen, sino que, por el contrario, se pretende rescatar el uso de la imagen como parte fundamental de un amplio análisis capaz de contener dentro de sí memorias y expresiones sociales que permitan exponer las contradicciones imperantes en la vida moderna, una vida que obliga o vuelve indispensable el ocultamiento del funcionamiento de la realidad para que en la práctica cotidiana permanezcan vigentes las formas institucionalizadas de la sociedad. Por ello planteamos que los juicios, las ideologías y preferencias de los que operan el aparato, los que crean la imagen, los que la interpretan, así como de los que encargan las imágenes, etc., no son neutrales, sino que están inmersas en un mundo complejo, contradictorio y construido sobre dinámicas cotidianas que reproducen y favorecen una práctica material determinada, muchas veces acorde con el discurso dominante.

Palabras clave

\begin{abstract}
In this paper, critical discourse is used as a fundamental element of what it's called the Critical History of the Gaze. The text does not try to establish a mere method of interpreting the image, but on the contrary, to use the image as an important part of a broad analysis capable of containing within itself memories and social expressions that allow the social scientist to expose the contradictions in modern life, a life that conceals the functioning of reality so that in daily practice the institutionalized forms of society remain unaltered. For these reasons, the paper goes further and state that the judgments, ideologies and preferences of those who operate the apparatus, those who create the images, those who interpret them, as well as those who classify them, etc., are never neutral, but immersed in a complex, contradictory world, built on everyday dynamics that reproduce a specific material practice, often in accordance with the dominant discourse.
\end{abstract}

Key words

History-critique-gaze - Image-object - Image-act dominant discourse - ideology - dominance

Historia-crítica-mirada - Imagen-objeto - Imagen-acto

- discurso dominante - ideología - dominio

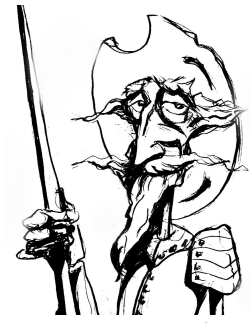

Recibido con pedido de publicación el 10 de junio de 2018 Aceptado para su publicación el 12 de septiembre de 2018

Versión definitiva recibida el 15 de noviembre de 2018

Fabiola Jesavel Flores Nava, Facultad de Economía (Área Historia Económica), Universidad Nacional Autónoma de México, México; e-mail: fabiolafloresn@gmail.com

\footnotetext{
* Este artículo fue escrito durante mi estancia posdoctoral como Becaria del Programa de Becas Posdoctorales. Instituto de Investigaciones Sociales, UNAM, 2013-2015. Agradezco los comentarios de los árbitros anónimos de esta publicación.
}

Esta obra se publica bajo licencia Creative Commons. Atribución-NoComercial-CompartirIgual 4.0 Internacional

Flores Nava, Faviola J. “Hacia una historia crítica de la mirada. Repensando el uso de la imagen dentro de las ciencias sociales", Prohistoria, Año XXI, núm. 30, dic. 2018, pp. 209-239. 
Vivimos una época en la que todo parece estar constituido por lo visual. Un mundo visual que estimula cotidianamente nuestra mirada a través de un cúmulo de imágenes que nos bombardean día y noche, en la casa, en la calle, en la escuela, en el trabajo, en nuestras pláticas, etc. Un suceso que parece generalizar o desrealizar "completamente el mundo humano de los conflictos y los deseos, con la excusa de ilustrarlo" ${ }^{1}$ y presentarlo como verdadero. Este hecho ha cautivado la atención de muchos científicos sociales que se han dado a la tarea de desarrollar múltiples enfoques sobre cómo interpretar estos fenómenos socio-históricos haciendo uso de las propias imágenes, por lo que han planteado diversas estrategias de análisis y marcos teóricos como medio para aproximarse a dicho conocimiento de la realidad representada. ${ }^{2}$

Para el análisis de la imagen, la Bildwissenschaft y los Visual studies han "contemplado los fenómenos de la imagen y la visualidad para procurar nuevas maneras de 'pensar y medir' los pilares en que se sustenta la teoría de la imagen". ${ }^{3}$ Cabe señalar también que la imagen ha sido abordada desde diferentes disciplinas como la filosofía, la antropología visual, la historia del arte, los estudios culturales, la semiótica, la historia, etc., y que cada una de ellas ha brindado elementos muy relevantes a su estudio, tanto en términos metodológicos como teóricos.

En ese sentido, aunque en este escrito se recuperan algunos de los elementos metodológicos abiertos por la hermenéutica de la imagen, ella no es la base teórica determinante de nuestra propuesta, la cual pretende, en primer lugar, rescatar el discurso crítico como fundamento de la historia de la mirada, $\mathrm{y}$, en segundo, a partir de dicho discurso, rescatar el uso de la imagen como parte importante de un amplio análisis capaz de contener dentro de sí memorias y expresiones sociales que permitan exponer las contradicciones imperantes en la vida moderna. ${ }^{4}$ Por ello, este escrito no es un método de

\footnotetext{
1 "Ved lo que ocurre en Estados Unidos: todo se trasforma allí en imágenes; se produce y se consume más que imágenes. Un ejemplo extremo: entrad en una sala porno de Nueva York; no encontraréis el vicio, sino solo sus cuadros vivientes; diríase que el individuo anónimo que en ellas se hace encadenar y flagelar solo concibe su placer cuando ese placer adopta la imagen estereotipada del sadomasoquista: el gozar pasa por la imagen: esta es la gran mutación". BARTHES, Roland La cámara lúcida, Paidós, Barcelona, 1980, p. 176.

${ }^{2}$ Los autores más clásicos, citados en muchos de los textos referente a estos temas, son: Walter Benjamín, con sus libros La obra de arte en la época de su reproductibilidad técnica y Pequeña historia de la fotografía; Roland Barthes, con su libro La cámara lúcida; Gisele Freud, La fotografía como documento social; Susan Sontag, Sobre la fotografía, editado en los años ochenta; Pierre Bourdieu, La fotografía: un arte intermedio, publicado a finales de los años setenta; Philippe Dubois, El acto fotográfico; Joan Fontcuberta, con su libro El beso de Judas. Textos un poco más actuales son los publicados por Marcus Banks y Didi-Huberman. En México, Chile, Brasil y Argentina encontramos también una amplia gama de autores que escriben sobre el uso de la fotografía en las ciencias sociales.

${ }^{3}$ MCPHAIL, Fanger Elsie Desplazamientos de la Imagen, Siglo XIX, México, 2013, p. 91.

${ }^{4}$ Sobre este tema, el historiador Carlo Ginzburg escribió un trabajo muy interesante acerca de la iconografía política en su libro Miedo, Reverencia, Terror, publicado en 2015 por Contrahistorias, la otra mirada de Clío.
} 
interpretación de la imagen en sí, sino un intento de fundamentar teóricamente la historia de la mirada desde el discurso crítico a partir del uso de determinadas imágenes, con la finalidad de indagar las formas en las que se construye la concepción de nuestro mundo circundante desde un cúmulo aparentemente desarticulado de representaciones confusas.

Esta interpretación parte de la consideración de que, desde hace más de 50 años, las estructuras de saber del mundo moderno han entrado en un proceso de reorganización cada vez más radical. Ello no significa, por supuesto, que antes no hubieran sufrido transformaciones y cambios, sino que la particularidad de esta última etapa radica en el cuestionamiento que se ha hecho a los paradigmas en que se fundaron los saberes modernos, es decir (refiriéndonos particularmente a las ciencias sociales), al cuestionamiento radical de aquel objetivo que pretendía convertir esos saberes en ciencias neutrales y objetivas, basadas en precisiones exactas y cuantificables.

En especial, los estudios históricos batallaron desde su origen por hacer posible la construcción de un discurso "objetivo" a través de la utilización de fuentes y documentos escritos. Dichos instrumentos le dieron sustento "verídico" a las narraciones de los historiadores, sustento con el cual se pretendió develar el pasado tal y como había sido visto por los participantes de una época. Como complemento de esta labor "científica", se consideró también que si el documento resultaba "falso" tenía que ser sometido a la "Quellen Kritik" (crítica de las fuentes). De esta manera, la investigación científica del historiador quedó legitimada gracias a la vinculación con la evidencia empírica, sometida a una revisión "crítica". Con ello se pretendió alejar al historiador de toda interpretación subjetiva que pudiera manchar, con sus valoraciones, los hechos del pasado.

Pero desde esta visión, ¿qué verdad se está protegiendo? ¿qué tipo de saber se está promoviendo? ¿qué tipo de valores subjetivos debe ocultar el historiador para desarrollar esta línea epistemológica? Las respuestas a estas preguntas no son fáciles, y el presente trabajo no pretende dar una última respuesta. Sin embargo, sí nos interesa señalar que precisamente los paradigmas en que se institucionalizaron las ciencias sociales estuvieron directamente relacionados con una etapa histórica del desarrollo del sistema capitalista. Esto es, la búsqueda de una única verdad, el supuesto establecimiento de la neutralidad en la historia y la imposición de un saber dirigido a organizar científicamente el mundo social, estaban en contacto directo con la preponderancia de la ideología liberal-centrista como elemento 
determinante de la geocultura dominante de finales del siglo $\mathrm{XIX}^{5}$ y gran parte del XX.6

La búsqueda de la verdad, la neutralidad del científico social y la posibilidad de un orden científicamente comprobable del mundo concreto tenían que respetar los parámetros en que se había construido y se encontraba funcionado histórica, política, económica y socialmente hablando, la moderna sociedad capitalista, por lo que los saberes modernos debían poner los fundamentos científicos-sociales que permitieran el potenciamiento de este sistema-mundo. ${ }^{7}$ De modo que el sueño de convertirse en algún momento en ciencias rigurosas, objetivas, exactas y precisas, ha sido utilizado para potenciar un discurso ideológico dominante. Es decir, la ciencia social,

“inspirada en la filosofía científica o 'positiva' -esto es 'constructiva', respetuosa de lo dado, aquiescente con el orden establecido, unificadora de los espíritus-, fue puesta en pie para combatir las doctrinas comunistas, continuadoras de la filosofía crítica o 'negativa' -esto es, 'destructiva', cuestionante, frente a la empiria, impugnadora del poder, deslindadora de los intereses históricos". ${ }^{8}$

Otro hecho importante fue que, ante los sufrimientos y horrores que causaron los sistemas totalitarios (justificados teóricamente por las ideas de universalidad y de sentido histórico unívoco, propias del capitalismo ${ }^{9}$ y del

5 "Las ciencias sociales se institucionalizaron solo a fines del siglo XIX, y a la sombra del predominio cultural de la ciencia newtoniana. Enfrentadas al discurso de las 'dos culturas', las ciencias sociales internalizaron esa lucha bajo el conocido debate de la Methodenstreit, o disputa metodológica. (Unas) pusieron el acento en la particularidad de los fenómenos sociales, la utilidad limitada de las generalizaciones, y la necesidad de empatía para la comprensión del objeto de estudio. (...) Los partidarios (de la nomotética) se cerraron en el paralelismo lógico entre los procesos humanos y los demás procesos materiales, y en consecuencia, utilizaron los métodos de la física en su búsqueda de leyes universales simples, cuya verdad permaneciera intacta a través del espacio y el tiempo". WALLERSTEIN, Immanuel "Las ciencias sociales en el siglo XXI", en Contrahistorias. La otra mirada de Clío, núm. 25, México, 2015, p. 85.

${ }^{6}$ Cfr. WALLERSTEIN, Immanuel El moderno sistema mundial. El triunfo del liberalismo centrista, 1789-1914, Editorial Siglo XXI, México, 2014, pp. 307-377.

7 "Las ciencias sociales surgieron como respuesta a problemas europeos en un momento de la historia en el que Europa dominaba todo el sistema mundo. Era prácticamente inevitable que la elección de su objeto, su teorización, su metodología y su epistemología reflejaran todas las fuerzas del crisol en el que se forjaron". WALLERSTEIN, Immanuel "El eurocentrismo y sus avatares: los dilemas de las ciencias sociales", en New Left Review, número 0, editorial Akal, España, 2000, p. 98.

${ }^{8}$ ECHEVERRÍA, Bolívar "Definición del discurso crítico", en Contrahistorias. La otra mirada de Clío, núm. 25, México, 2015, p. 35.

9 “Una universalización necesariamente antitética y desgarrada, que en la práctica se impone como el intento de nivelación y subsunción de todos los pueblos a un solo y particular proyecto civilizatorio - es sin duda el proyecto europeo occidental en su variante nórdica. [...] Porque lo 
socialismo real), gran parte de la izquierda intelectual se encontró cada vez más limitada al desarrollo de temas apartados de cualquier mínimo rasgo de esencialismo típicos de la visiones universalistas. Los trabajos de intelectuales críticos como E.P. Thompson, Eric Hobsbawm, Roland Barthes, Pierre Bourdieu, Michel Foucault, Jaques Derrida, Gilles Deleuze, Raymond Williams, Hélène Cixous, George Bataille, Slavoj Žižek, etc., forman parte de una herencia teórica que logró innovar de muchas manera el estudio de lo social-humano al cuestionar la vieja idea de que hay verdades universales y esenciales que atraviesan todo tiempo y todo espacio, gobernando la conducta humana. ${ }^{10}$ En todos estos autores se muestra también una clara aversión hacia esa mirada cientificista de la historia asumida como continuidad en el tiempo y en cuyo devenir se encuentra ya la marca ineludible de una verdad histórica.

Trabajos como los de Michel Foucault, por ejemplo, proponían desenterrar de la historia aquellos temas que, bajo la idea del progreso y de un discurso político liberador, ocultaban los avances de una sociedad disciplinaria. Siguiendo esta idea, Foucault propuso la investigación desmitificadora de temas muy novedosos y controvertidos, poniéndola en práctica en sus análisis sobre el desarrollo (dentro de la modernidad) de lo que se consideró tradicionalmente como locura, prisión, castigo, sexualidad, etc. "Foucault no procura captar las continuidades que se anuncian al enunciar nuestro mundo; al contrario, señala las discontinuidades, las oscilaciones de las epistemes. La eficacia del saber histórico estriba en problematizar, en romper las constancias, el juego consolador de los reconocimientos". ${ }^{11}$

Lo que, sin embargo, ha resultado más impactante para las ciencias sociales es el modo y el grado en que los estudios teórico-políticos han ido cediendo terreno a los estudios culturales (antiesencialistas), dando paso a un desplazamiento temático que, surgido desde las humanidades (especialmente

que las diversas filosofías de la historia expresaron fue justamente el lado 'universalistaabstracto' de la modernidad, lado que, apoyado en la lógica y naturaleza igualmente universales y abstractas del valor, se hizo valer como progreso histórico civilizatorio frente al localismo, particularidad y aislamiento de las distintas historias de los pueblos y sociedades precapitalistas". AGUIRRE ROJAS, Carlos "Repensando las ciencias sociales actuales", en Revista Mexicana de Sociología, Vol. 61, núm. 2 (Apr-Jun), 1999, pp. 63, 69.

${ }^{10}$ Sin olvidar que antes de ellos hubo toda una generación de pensadores que, con su riqueza intelectual, lograron abrir muchas puertas para el estudio crítico de la sociedad capitalista, ya no pensada unilateralmente como totalidad organizada desde un centro fijo (sea este económico, político, etc.), sino como totalidad que incluía diversas particularidades irreductibles a un ámbito específico, consideradas incluso desde espacios variados de la cultura. Me refiero sobre todo a autores como Walter Benjamín, Henri Lefebvre, Antonio Gramsci, Lucien Febvre, Wilhelm Reich, Theodor Adorno, Max Horkheimer, Ernst Bloch, Jean-Paul Sartre, Claude Levi-Strauss, Norbert Elias, Marc Bloch, etc.

${ }^{11}$ DOSSE, Francois La historia: conceptos y escrituras, Editorial Nueva visión, Buenos Aires, 2000, p. 154. 
desde la filosofía), ha repercutido severamente en sus distintas áreas de investigación. Como bien se sabe, desde hace tiempo, los temas que giran alrededor de conceptos como etnia, género, cuerpo, libro, etc., se han vuelto el material de trabajo predominante de las investigaciones académicas. El cuestionamiento a estas investigaciones es que por centrarse solo (por poner un ejemplo) en el género, se olvidan de los conflictos de clases y de las profundas contradicciones que genera la vida moderna.

En términos generales, con estos señalamientos, la intención es ubicar el presente escrito dentro de un discurso crítico, que haciendo uso de un determinado tipo de reflexión sobre la historia crítica de la mirada, como parte del análisis histórico-social, nos permita criticar las formas en que se llevan a cabo las dinámicas cotidianas en la vida social moderna. Partimos de la idea de que las imágenes son formas o creaciones inmersas en actos sociales estrechamente vinculados a un contexto histórico-social, por ello la imagen que aquí nos interesa buscar es aquella que contiene dentro de sí una multitud de herencias, no solo de valores visuales, sino también de valores discursivos. Esta valoración presenta una dificultad implícita que envuelve diversos significados, significados que van más allá del ámbito meramente imaginativo; la imagen dificulta su interpretación, justo porque gran parte de los temas vinculados a procesos históricos, sociales y económicos aparentemente no pueden ser capturados por los soportes en los que las miradas creadoras de imágenes visuales transforman o "traducen" la "realidad" observada.

De este modo, para vincular las imágenes con sus respectivos contextos, haremos uso de la historia crítica de la mirada, ${ }^{12}$ mirada que está constituida por las condiciones en que se sitúa frente a los múltiples tiempos y épocas históricas, considerando que la misma mirada construye imágenes que se vuelven interpretaciones inevitables de ciertos temas. De este modo, la historia social de la mirada queda adscrita a los horizontes de complejidad creados por la comprensión de una época. Por lo demás, cabe señalar la importancia que tiene el hecho de que dentro de cada tiempo histórico pueden surgir enfoques múltiples y diversos vinculados a la forma jerarquizada en que se estructura lo social humano, desde el cual se comparten, así como se ponen en contradicción, perspectivas y constelaciones de intereses presentes entre las diferentes clases sociales.

\section{Proceso indirecto del mirar individual}

12 Esta idea ha sido trabajada en varios escritos históricos que he publicado en diferentes revistas tanto nacionales como de América Latina. 
El ejercicio de la historia crítica de la mirada comienza en el momento en el que se quiere hacer inteligible un proceso espontáneo en apariencia, pero, al igual que la historia, está marcado por una estructura jerarquizada del mundo social que afecta el cómo y el qué miramos. Este modo de pensar la historia requiere, por así decirlo, mirar las miradas, el cómo y el qué se mira, quién mira y bajo qué contexto social e intelectual mira. Al mismo tiempo, es necesario que dicha concepción se introduzca en el análisis de las diferentes contradicciones, conflictos sociales e históricos, que abarcan, a su vez, diferentes tiempos. La propuesta, consiste, entonces, en abordar las imágenes pensando que ellas son documentos históricos que pueden ser traducidos y desde los cuales se pueden sacar a la luz tanto las negatividades y contradicciones presentes en los hechos y fenómenos históricos, como las propuestas transformadoras de esos mismos fenómenos.

El mirar implica una cierta concepción y experiencia ${ }^{13}$ del mundo circundante, un horizonte de sentido creado alrededor del ser o el grupo de seres que miran; es el producto de un sistema de disposiciones que se adquieren en un contacto continuo con las condiciones sociales de existencia. El mirar tiene un sentido práctico. El acto de mirar es afrontado también, en su dimensión social e histórica, como un acto que pone en juego relaciones de poder y dominación entre los que ejercen este práctica, por lo que en ella se determinan también ciertas visiones -en virtud de su posición social- respecto a los diferentes actores sociales (estos pueden ser: clases sociales, grupos étnicos, mujeres, niños, viejos, trabajadores, grupos empresariales, grupos gobernantes, partidos políticos, etc.). ${ }^{14}$

Para aclarar este punto hemos de poner un ejemplo desarrollado en otros artículos, en los que he tratado el tema de la historia crítica de la mirada. El ejemplo al que me refiero es a la construcción de la mirada antropológica y su vínculo con algunas investigaciones sobre los pueblos indígenas durante los últimos años del siglo XIX y principios del XX.

\footnotetext{
${ }^{13}$ La experiencia está vinculada a la relación y a la actividad que el individuo o los individuos tengan con respecto a su posición social dentro del proceso de reproducción de la vida sociomaterial, y como este proceso se vincula a sus horizontes de sentido, a la conciencia que desarrolla del mundo que lo rodea.

${ }_{14}$ "...de modo que la fotografía más insignificante expresa, además de las intenciones explícitas de quien la ha tomado, el sistema de los esquemas de percepción, de pensamiento y de apreciación común a todo un grupo". BOURDIEU, Pierre "Introducción", en La fotografía: un arte intermedio, Compilador: Pierre Bourdieu, Editorial Nueva Imagen, México, 1979, p. 22. "Nunca está demás enfatizar que este contenido es el resultado final de una selección de posibilidades de ver, optar y fijar un cierto aspecto de «espacio y tiempo», cuya decisión cabe exclusivamente al fotógrafo, ya sea que esté registrado el mundo para sí mismo o al servicio de un comitente [...] En esa selección reside una primera manipulación \interpretación de «espacio y tiempo»; sea consciente o inconsciente, premeditada o ingenua, esté al servicio de una o de otra ideología política". KOSSOY, Boris Fotografía e historia, Ática, São Paulo, 1998, p. 83.
} 
Si el mirar implica una cierta concepción y experiencia del mundo circundante, un horizonte de sentido creado alrededor del ser o el grupo de seres que miran, ¿cuál es el punto de partida del mirar antropológico del siglo XIX y principios del XX?

La visión antropológica, que se encuentra dentro de la construcción de los saberes modernos, desarrolló una identidad con el funcionamiento de la vida moderna, fue creando determinadas miradas en las que algunos sectores de la sociedad eran vistos como grupos poblacionales incivilizados o poco aptos para ser sujetos de las dinámicas económicas impuestas por la expansión de la sociedad capitalista.

Estos saberes establecieron en su momento planteamientos precisos sobre qué y cómo se tiene que ver. Lo hicieron sobre métodos de observación, descripción y análisis, utilizando instrumentos técnicos y conceptuales que configuran y reconfiguran una forma de ver el mundo. La imagen es el producto de una mirada sobre el mundo, utiliza diagramas, esquemas, dibujos y otras formas de representación pictórica. Otras veces, incorpora la fotografía como ilustración o complemento del texto y utiliza también las nuevas tecnologías visuales y de sonido como instrumentos para el tratamiento de datos, al igual que como forma de expresión de sus conclusiones y hallazgos. Pero esta forma de analizar, sobre la que se desarrolló la ciencia antropológica, se encuentra en correspondencia con una determinada época histórica, es decir identificada con determinado discurso dominante, cuya producción y consumo de significantes está estrechamente ligado al mantenimiento de un determinado orden social impuesto cotidianamente por la forma en que se produce y reproduce la sociedad moderna capitalista. En ese sentido, la mirada de los primeros antropólogos hacia los indígenas estuvo enmarcada por la idea, muy difundida durante el siglo XIX, de que el hombre y la civilización occidental eran el pináculo del desarrollo humano. De tal modo que el acto de mirar, afrontado en su dimensión social e histórica, puso en juego relaciones de poder y dominio. Por ello es pertinente mencionar que los antropólogos que llegaban a los diferentes lugares en los que hacían sus estudios, provenían normalmente de las principales potencias colonizadoras, por lo que sus visiones sobre los países conquistados estaban marcadas por relaciones de poder y dinámicas económicas de explotación.

En ese sentido, muchas de las miradas vueltas imágenes por estos grupos eran utilizadas, en algunos casos, como pruebas irrefutables de que no todos los grupos humanos se encontraban en el mismo nivel evolutivo de las civilizaciones europeas y que, por lo mismo, existían lugares (fuera de Occidente) donde podían descubrir características "primitivas" que ayudaran a entender el pasado del hombre y la evolución humana hacia su forma moderna. Numerosas ideas de este tipo fueron asumidas por diversos Estados nacionales 
que intentaron "blanquear" a sus poblaciones, no solo mediante la imposición de las nuevas prácticas modernas propias de la expansión de la Europa capitalista, sino también, ideológicamente hablando, mediante la difusión corpórea de un nuevo tipo de hombre.

Ahora bien, en el acto de mirar se crean determinadas visiones o concepciones, en virtud de su posición social, alrededor de determinados actores sociales, como en el caso anterior respecto de los "otros" mundos. De este modo, la construcción de la mirada sobre los diferentes actores sociales es el resultado de las permanencias y los cambios en el desarrollo histórico del contexto social en el cual se ha desenvuelto su actividad práctica. Por lo que, dentro del desarrollo de la modernidad, se han rescatado a lo largo del tiempo los rostros, las representaciones, los símbolos, la diversidad cultural, la homogeneidad, la catalogación, el costumbrismo, la pobreza, etc., de diferentes actores sociales y sobre ellas se han proyectado un sinnúmero de ideologías, estereotipos, intereses científicos, propuestas estéticas, etc., que muchas veces han coincidido con determinadas líneas de pensamiento, así como con ciertas políticas gubernamentales, institucionales, artísticas y sociales. Debido a ello es que podemos indagar sobre las miradas que se han formulado sobre estos sujetos sociales. Sin embargo, y aquí el límite del simple mirar, los actores sociales no luchan solo por cambiar la construcción de determinada mirada, más bien viven en determinadas circunstancias sociales e históricas, y en su práctica y actuar se van creando o transformando a sí mismos, creando con ello nuevas visiones que contradicen o refuerzan la forma en que se les mira.

Hasta aquí hemos considerado entonces al sujeto o grupo de sujetos que miran, al sujeto o actor social que es mirado, así como también la importancia de las condiciones socio-históricas sobre las que ambos sujetos sociales se desenvuelven. Ahora nos interesa pasar a entender otro de los procesos que permite entender cómo las miradas se convierten en imágenes y, en ese sentido, elaborar con mayor precisión los elementos que nos ayuden a hacer uso de la imagen como documento histórico-social. Cabe señalar que nosotros hemos trabajado sobre todo con la imagen fotográfica, así que nos enfocaremos en ella.

“Las fotografías son mundos de relaciones silenciosas, densas, congeladas en el tiempo mínimo del obturador. Mundos de seres callados e inmóviles que deben ser descifrados a partir del contexto donde se encuentran, en la historia de su relación con los demás seres, tanto personas como objetos. Es el conocimiento de esas relaciones ocultas, expresiones complejas del mundo de la cultura, lo que permite que nos aproximemos a las fotografías más allá del placer estético, de su encanto 
inmediato. Es éste el camino tortuoso de la fotografía como fuente histórica" ${ }^{15}$

\section{El proceso directo del mirar individual frente a lo social (de la imagen-objeto a la imagen-acto)}

Como parte de la historia crítica de la mirada, la fotografía no representa, en ningún sentido, una mirada inocente de lo que retrata, sino que, muy al contrario, es en todo momento parte de una sociedad y de una cultura, y, por lo mismo, recibe inevitablemente de ellas diferentes valores que quedan plasmados en las representaciones visuales que nos ofrece. La imagen no es una simple huella o un index, esta no representa una realidad en sí, más bien, a partir de ella se ha creado otra cosa diferente al sujeto $u$ objeto retratado, aunque para llegar a su comprensión se tenga que dar un rodeo.

"Se habrá comprendido que no hay, de un lado, la imagen, material único, inerte y estable, y, de otro, la mirada, como un rayo de sol móvil que viniera a animar la página de un libro grande abierto. Mirar no es recibir, sino ordenar lo visible, organizar la experiencia. La imagen recibe su sentido de la mirada, como lo escrito de la lectura, y ese sentido no es especulativo sino práctico [...] Las culturas de la mirada, a su vez, no son independientes de las revoluciones técnicas que vienen a modificar en cada época el formato, los materiales, la cantidad de imágenes de que una sociedad se debe hacer cargo [...] Más que visiones, ahí hay organizaciones del mundo". ${ }^{16}$

Lo que se intenta hacer mediante esta propuesta es no aislar a la imagenacto $^{17}$ de todas las condiciones históricas y sociales implicadas en la acción de crear la imagen-objeto. La complejidad de la imagen fotográfica se deriva de que su existencia exige distintas formas de identidad, así como distintos modos de abordarla, esto es, por su relación con el fotógrafo o creador de una imagen, con el referente y su relación con la realidad, con el objeto-fotografía en sí mismo, con el aparato técnico, con el contacto de la imagen y su mundo circundante -dónde circula, quién lo encarga, quién lo lee, quién la utiliza y

\footnotetext{
${ }^{15}$ CIAVATTA, Maria "Educando al Trabajador de la gran «familia de la fábrica». Memoria, historia y fotografía", en Imágenes e investigación social, coordinado por Fernando Aguayo y Lourdes Roca, Instituto Mora, México, 2005, p. 360.

16 DEBRAY, Régis Vida y muerte de la imagen. Historia de la mirada en Occidente, Paidós Comunicación, México, 1994, pp. 38-39.

${ }^{17}$ Le llamo imagen-acto, pensando en el proceso de creación, porque en ella hay toda una serie de redes complejas de elecciones, actitudes, comportamientos, etc., que la componen, y que parten del sujeto que la produce.
} 
para qué, etc.-, con la ausencia material del referente -pérdida del aura (Walter Benjamin)-, con los diferentes géneros a los que pertenece la fotografía documental, artística, familiar, periodística, antropológica, etnográfica, etc.

"Solo los teólogos sueñan con imágenes que no hayan sido producidas por la mano del hombre [...] La cuestión es, más bien, cómo lo ha hecho y para qué, con qué propósito tuvo lugar la manipulación. Para bien o para mal, usamos nuestras manos, asentamos golpes o acariciamos, construimos o destruimos, damos o tomamos. Frente a cada imagen, lo que deberíamos preguntarnos es cómo (nos) mira, cómo (nos) piensa y cómo (nos) toca a la vez". ${ }^{18}$

Por dichas complejidades es que se propone pensar la imagen como una totalidad que se encuentra relacionada prácticamente con quien la crea, la consume y la interroga, y en cada uno de estos elementos se encuentra su conexión con el análisis de la totalidad. Lo que llamo historia crítica de la mirada interviene de forma particular y global, tanto en la imagen-acto como en la imagen-objeto.

¿Qué vehicula, entonces, esa relación práctica entre la forma imagen y los distintos sujetos sociales que se relacionan con dicha forma? Aunque en apariencia ciertas fotografías parecen no tener que ver con significados precisos, "pues ésta son una nebulosa de contenido", 19 hemos tratado de romper con esta idea señalando que al no depender del puro azar o de una intención accidental, existe un camino crucial para llegar o aproximarnos a alguno de los significados ocultos tras la forma imagen-objeto-fotográfico.

Si damos un paso más, notaremos que la revelación del secreto no basta, es decir, la revelación del misterio humano tras la forma no es suficiente, es importante ahondar aún más en la génesis de la forma de la imagen-objeto, en el proceso mediante el cual el contenido oculto se devela en determinada forma y no en otra. Es decir, cómo la inaccesibilidad al contenido de la imagen o su parcial acceso tiene una efectividad en el mundo social, en el sentido en que el que observa la forma imagen-objeto-fotográfico, actúa como si esta no hubiera estado sometida a cambios físicos, materiales, sociales, ideológicos, políticos, etc., es decir, como si estuviera excluida de un ciclo, de una génesis, o fuera de una complejidad de contradicciones y conflictos sociales que pueden llegar a

${ }^{18}$ DIDI-HUBERMAN, Georges “Cómo abrir los ojos", prólogo del libro Desconfiar de las imágenes de Harun Farocki, Caja Negra, Argentina, 2013, pp. 13-14.

${ }^{19}$ ECO, Umberto Una semiótica y filosofía del lenguaje, Editorial Lumen, Barcelona, 2000, p. 257. 
expresarse, curiosamente, de acuerdo o en contradicción con el discurso dominante. ${ }^{20}$

Esta consideración de la fotografía como reflejo de la realidad ha dado pie, entre otras cosas, a que sea empleada, por un lado, como una forma de preservar y conocer en retratos, álbumes, revistas, periódicos, etc., el estado que guarda un grupo, una familia, un individuo, un objeto o la sociedad en un periodo determinado, $\mathrm{y}$, por el otro, a que sea utilizada como una forma de engaño, especialmente desde la publicidad. A diferencia de lo que se puede pensar, un tipo de aproximación no excluye, de ningún modo, el otro. Al contrario, sin uno de ellos es difícil entender el otro. Si no se viera en la fotografía la posibilidad de mostrar un momento, un estado de cosas, la publicidad difícilmente la hubiera hecho suya.

Al respecto del funcionamiento de la realidad, Slavoj Žižek hace una exploración muy interesante en su libro El sublime objeto de la ideología. ${ }^{21}$ Retomando a Marx, a Freud y a Lacan, nos recuerda que esta ya funciona cotidianamente, en su forma fetichizada, como fantasía, es decir, que el hombre se desenvuelve sobre un mundo de apariencias que dominan el mundo concreto o, como diría Karel Kosik, la realidad pseudoconcreta. ${ }^{22}$ De modo que si la realidad es una ficción, que se "adapta y adaptamos" a nuestras propias narraciones y deseos, la fotografía no puede ser un reflejo pleno de ella misma porque esta funciona ya de forma fetichizada. Sin embargo, el hecho de que muchas de las imágenes creadas -por la publicidad, por ejemplo- puedan manipular nuestra mirada haciéndonos creer y desear aquello que nos presentan como la realidad misma, es una situación que implica un circulo que legitima a la imagen-objeto como real, es decir, como un espacio donde se funda lo real a través de la imagen.

Atendiendo a estos señalamientos, resulta interesante entonces entender cómo se internalizan los aspectos fenoménicos de la realidad en un individuo y de allí en la imagen. Por ejemplo, cuando aprendemos a desear el mundo de las apariencias, de las formas fetichizadas, estos deseos se ven reflejados en nuestras miradas, y estas, a la vez, van creando nuestros horizontes visuales con los que construimos ciertas posiciones ante el mundo, y en ese sentido, de algún modo, formamos y elegimos una manera de aprehender a desarrollar, o no,

\footnotetext{
${ }^{20}$ Es también lo que el filósofo checo Vilém Flusser dice, en términos parecidos, cuando asegura que el simple observador considera que lo que presenta una fotografía es una situación que de algún modo proviene del mundo exterior. Ingenuamente el observador puede llegar a aceptar virtualmente que puede mirar el mundo a través de las fotografías, lo cual mostraría que el mundo de las imágenes es congruente con el mundo externo. FLUSSER, Vilém Una Filosofia de la fotografía, Editorial Síntesis, España, 1983, pp. 21-32.

${ }^{21}$ ŽIŽEK, Slavoj El sublime objeto de la ideología, Editorial Siglo XXI, México, 2012, pág. 302.

${ }^{22}$ KOSIK, Karel Dialéctica de lo concreto, Editorial Grijalbo, México, 1970.
} 
aquello que nos presenta la realidad pseudoconcreta ${ }^{23}$ como real. Esta posición termina por regular nuestra vida más que la verdad misma.

Partir, entonces, del proceso del mirar individual es partir del punto donde el sujeto creador de la imagen-acto desarrolla su horizonte visual en estrecha relación con una serie compleja de normas, leyes, instituciones y estructuras simbólicas que organizan la figura concreta de la vida social; para que dichas normas, leyes y estructuras se auto-reproduzcan y resulten necesarias en su visión del mundo, es importante que estas formen parte de un código general o de diversos códigos que organicen las posibilidades concretas de su comunicación o significación. ${ }^{24}$ Estos códigos tienen un contenido material, son producto de la praxis humana, de la forma en que se lleva a cabo el proceso histórico concreto de la reproducción social, y su contenido parte de allí pero se diversifica y complejiza dependiendo del punto de partida sobre el cual se construya su significado. ${ }^{25}$

Por ejemplo, en la sociedad capitalista lo práctico inerte (Sartre) funciona cuando la reproducción social está sometida a la forma en que se desenvuelve el proceso de valorización del capital. En ese sentido, la creación de códigos dominantes lleva en sus entrañas determinados significados que están calificados de positivos o negativos en referencia a toda acción social histórica concreta que impulse dicha forma. El sujeto social (proletario) sabe que para vivir en la sociedad moderna tiene que vender su fuerza de trabajo -venderse para recibir un salario-, pues de lo contrario entra en peligro su existencia material. Podemos decir que se conocen los pasos para ser un esclavo moderno, y esto es así porque pocos pueden escapar de esta realidad. Pero, para que

${ }^{23}$ "La ideología es de hecho todo proceso de reducción y de abstracción del material simbólico en una forma; pero esta abstracción reductora se da inmediatamente como valor (autónomo), como contenido (trascendente), como representación de conciencia (significante)". BAUDRILLARD, Jean Crítica de la economía política del signo, Siglo XXI, México, 2002, p. 168.

24 "El conjunto de leyes de acuerdo al cual se organizan las posibilidades de figuras concretas del sujeto social en su auto reproducción implican un código general que organiza las posibilidades concretas de su comunicación o significar. Y así como ese conjunto de leyes cambian históricamente, lleva una tendencia estructural en su modificación y califica positiva o negativamente en referencia de ella a toda acción social posible, así también el código general sigue esa tendencia básica a su dinámica específica y califica de verdaderos o falsos, según se adecuen o no a ella, todos los mensajes concretos posibles". ECHEVERRÍA, Bolívar "Definición...", cit., p. 40.

25 "Lo social, el campo de las prácticas sociales y las creencias sostenidas socialmente, no se hallan simplemente a un nivel distinto de las experiencias individuales, sino que es algo con lo que debe relacionarse lo individual en sí, que lo individual en sí debe experimentar como un orden que está mínimamente reificado, externalizado. El problema no es, por consiguiente, «cómo pasar del nivel individual al social», sino cómo debería ser el orden externo-impersonal sociosimbólico de prácticas institucionalizadas si el sujeto pretende mantener su «cordura», su funcionamiento «normal»". ŽIŽEK, Slavoj Visión de paralaje, Fondo de Cultura Económica, México, 2011, p. 14. 
funcione la maquinaría simbólica de la realidad moderna, tiene que pensarse y vivirse como un hombre libre, que elige "voluntariamente" vender su fuerza de trabajo para reproducir su vida de la mejor manera que le sea posible. Sin importar que enajene y sacrifique en el camino su vida, lo importante es, cuando consigue comprador, ganar el dinero necesario para reproducirla. Esta forma "libre" de entregarnos voluntariamente a las fuerzas del mercado, encubre una forma particular de explotación moderna, pero en la realidad este hecho se nos presenta como el único posible si se quiere triunfar en la vida o continuar en pos de esa idea de libertad. Sin esta falsa idea de libertad, el vivir generaría una angustia insoportable y las contradicciones sociales e individuales estallarían a cada momento. La elección está allí, ya que aun sabiendo que dicha labor esconde una forma de explotación, al sujeto contemporáneo no le "queda de otra" más que sumarse a los "beneficios" de esta forma que adoptó el trabajo en la modernidad capitalista. En ese sentido, esta forma de vivir "hace posible que el vidente se cerciore de que no corre peligro en medio de su propio entorno" ${ }^{26}$

Esta realidad queda reforzada en el individuo en el momento en que este se reproduce prácticamente bajo los códigos tejidos por el discurso dominante; es decir, la maquinaria social regula nuestra actividad práctica, y al hacerlo construye un discurso rector de lo que es la realidad. Este discurso rector capta las fantasías del individuo, y en ellas se reproduce, las utiliza para dar forma a una ilusión simbólica. El sujeto persigue todas las fantasías que el discurso dominante presenta como las adecuadas para recrear esa realidad vivible, una realidad que le permita tener la ilusión de que se encuentra viviendo en el mejor de los mundos posibles. De este modo recibe y reproduce el mensaje que esta realidad le invita a desear, y en pos de esa "realidad liberada" produce y emite significaciones que le ayudan a continuar con esa determinada narración de su vida. Es producto y productor de esa vida.

En esta situación, el sujeto que mira y crea la imagen-acto debe recrear su propia identidad social, la cual puede, por un lado, desear los mismos códigos que emite la realidad de la estructura social simbólica dominante y continuar el camino de la identidad con el mundo pseudoconcreto, $\mathrm{y}$, al mismo tiempo, producir significaciones acordes con dicho discurso. Un significante se apodera de nosotros cuando consigue determinar nuestra experiencia cotidiana, por lo que un discurso triunfa cuando incluso los hechos que a primera vista lo contradicen empiezan a funcionar como argumentos a su favor (Slavoj Žižek). Los objetos prácticos creados muestran una expresión significante, un contenido social, que emite mensajes acordes con el funcionamiento

${ }^{26}$ Crf. SLOTERDIJK, Peter Esferas I, Biblioteca de Ensayo Siruela, España, 2014. 
ideológico, ${ }^{27}$ el cual estructura nuestra propia realidad social; esta actitud le permite al ser que mira cerciorarse de que no corre peligro; es una posición cómoda que permite al sujeto huir de la angustia de lo real (del vacío, de la nada), e incorporar una ficción narrativa que le posibilite seguir viviendo su cotidianeidad, una ficción que parte de la misma relación práctica del sujeto con el mundo. De este modo, nunca veremos a las personas, a los objetos y a lo real como realmente son, sino solo de la forma en la que las adaptamos a las coordenadas de nuestra posición ideológica y, en ese sentido, las representamos y las recreamos. (Mis deseos no son nada sino el simple hecho objetivo de que hay un espectáculo para ver tras la realidad cotidiana a la que me entrego; Slavoj Žižek).

En lo que se quiere insistir es que los significados del discurso dominante no se sitúan meramente en el pensamiento o no se encuentran flotando en el aire esperando a ser atrapados por alguien; no son una falsa conciencia, sino que están posicionados también en el hacer y construyen nuestra práctica cotidiana. ${ }^{28}$ El significante y el referente son el mismo, solo que lo que se reconoce falsamente en ellos no es la realidad, sino la ilusión que estructura su realidad, su actividad social real. ${ }^{29}$ Es, entonces, el ser social el que está soportado por la falsa conciencia, y su efectividad reside en que los individuos lo reproducen "sin saber lo que están haciendo"; pasan por alto la ilusión que estructura nuestra relación efectiva y real con la realidad. (Como diría Jean-Paul Sartre, una especie de mala fe).

27 "La función de la ideología no es ofrecernos un punto de fuga de nuestra realidad, sino ofrecernos la realidad social misma como una huida de algún núcleo traumático real”. ŽIŽEK, Slavoj El sublime..., cit., p.76.

28 "Para Žižek, no existe una mejor representación de las tensiones existentes entre la fantasía y la realidad que las películas de David Lynch. En las primeras imágenes de Terciopelo azul (Blue Velvet, EU, 1986) apreciamos distintas escenas de la pretendida vida idílica de un pequeño pueblo norteamericano. La cámara se centra de pronto en un hombre de edad que riega su jardín y que, repentinamente, sufre un ataque cardíaco. En lugar de preocuparse por dar cuenta de lo que sucede con el hombre y su familia, inmediatamente después del suceso, Lynch obliga a la cámara a acercarse al verde césped y a profundizar más allá de él, hasta mostrar los insectos y bichos que viven bajo su superficie. La película se sumerge así en una especie de sueño terrorífico, del cual el personaje central, Jeffrey (Kyle MacLachlan), tiene que huir para regresar a la seguridad de la realidad. Žižek propone entonces la siguiente interpretación: en lugar de la conocida frase "los sueños son para aquellos que no pueden soportar la realidad", el filósofo sentencia: "la realidad es para aquellos que no están en condiciones de enfrentar sus sueños". HERRERA, de la Fuente Carlos "Slavoj Žižek, el primer caso de un cinefilósofo", en Cinetoma Revista mexicana de cinematografía, Pasodegato ediciones, México, julio-agosto, 2016, p. 48.

${ }^{29}$ El nivel fundamental de la ideología, sin embargo, no es el de una ilusión que enmascara el estado real de las cosas, sino el de una fantasía (inconsciente) que estructura nuestra propia realidad social. "Ellos saben que, en su actividad, siguen una ilusión, pero aun así, lo hacen". ŽIŽEK, Slavoj El sublime..., cit., p. 61. 
Pueden saber que el ideal de belleza impuesto por el discurso dominante es una fantasía que manipula nuestras mentes y nuestra vida, y aun así hacen todo por alcanzarlo reproduciendo de algún modo todas las estructuras sociales que permiten que este ideal funcione efectivamente en la realidad y controle nuestro hacer cotidiano. "Saben que siguen una ilusión, pero aun así lo hacen". ${ }^{30}$

Una de las formas en que se comunica la realidad con la imagen-acto es por medio del mirar práctico del sujeto creador. Este puede recrear su identidad social también de forma crítica, es decir, si a través de sus objetos prácticos nos permite pensar visualmente, ${ }^{31}$ al presentarnos una ruptura con la identidad, con la forma, en que se construye el mundo de las formas fenoménicas. Con la imagen-acto se pueden mostrar las inconsistencias y criticar la forma misma en que funciona la realidad cotidiana; el sujeto creador, en este caso, debe mostrar las inconsistencias de la realidad y sus representaciones ideológicas para promover una toma de posición frente a la frágil estructura de los deseos que se identifican con el mundo pseudo-concreto bajo el cual lo real no existe. De este modo, el sujeto creador de la imagen-acto no está solo atado a una estructura de relaciones sociales y políticas que lo dominan (ni siquiera los puramente cínicos que reproducen en su totalidad el discurso dominante), sino que siempre hay una tensión constante entre la elección del individuo frente al contenido social de la realidad -de identidad plena, de crítica, de actitud cínica, romántica etc.y el contenido comunicativo que elige en su expresión individual, cualquiera que sea esta, con respecto a la estructura sobre la que se construye su realidad simbólica.

Ahora bien, para que la imagen-acto tome forma es necesario considerar también que el sujeto crea su mirada desde un horizonte de sentido visual, no solo el que le viene dado de su vínculo particular e innegable con lo social, sino también de su relación con los medios que utiliza para expresarse visualmente. Habría que hacer una aproximación a los contenidos de su formación visual, de sus líneas de trabajo, con el cómo y el dónde de su aprendizaje técnico de expresión visual, es decir, encontrar algunos de los elementos que nos permiten acceder a los contenidos aprehendidos en sus labores de formación como

\footnotetext{
${ }^{30}$ No es entonces la falsa conciencia de un ser social sino este ser en la medida en que está soportado por la falsa conciencia, puede gozar su síntoma solo en la medida en que su lógica se le escapa. La medida del éxito de la interpretación de esa lógica es precisamente la disolución del síntoma. ŽIŽEK, Slavoj El sublime..., cit., p.47.

31 "La diferencia entre el cine concebido como industria cultural y los grandes directores, es que los segundos logran tener autonomía en la forma de plantear y resolver los problemas cinematográficos. De esta manera nos permiten pensar visualmente. No presentan, simplemente, el mundo de las apariencias, sino la forma en la se construye, acercándonos a sus inconsistencias y, desde ahí, criticando la construcción misma de la realidad". HERRERA, de la Fuente Carlos “Slavoj Žižek...", cit., p. 49
} 
productor de imágenes. Esto es, encontrar los vínculos que existan con las herencias -con su pasado-, con las tendencias -con su presente-, o con las rupturas -con el futuro- visuales de la época, ya que, en muchos casos los rostros, las posturas, los símbolos de los creadores vienen modelados o son rupturas con las formas en las que se construyen los valores de otras miradas. Aun cuando la producción de la imagen sea enteramente adjudicada al automatismo de la máquina, la toma sigue siendo una elección que involucra valores estéticos y éticos. ${ }^{32} \mathrm{Y}$ son justo esos valores estéticos los que tenemos que investigar.

“Nunca está demás enfatizar que este contenido es el resultado final de una selección de posibilidades de ver, optar y fijar un cierto aspecto de «espacio y tiempo», cuya decisión cabe exclusivamente al fotógrafo, ya sea que esté registrado el mundo para sí mismo o al servicio de un comitente [...] En esa selección reside una primera manipulación\interpretación de «espacio y tiempo»; sea consciente o inconsciente, premeditada o ingenua, esté al servicio de una o de otra ideología política". ${ }^{33}$

Así, la articulación entre la imagen-acto (creación de significado) y el mundo (referente no fijo) se da a través de la mirada cuyo proceso antes descrito trae como resultado la imagen-objeto. En esta última pueden gobernar múltiples formas -clásica, romántica, barroca, moderna, vanguardista, etc.- y responder de modos muy variados a la abstracción racional de la realidad como fetiche, o elegir también el elemento creador de una crítica al mundo circundante; y puesto que el referente es un actor social cambiante, la vivencia individual/social también los es, por lo que la expresión de significados por medio de una imagen puede ser cómplice de la realidad que intenta interpretar o ser crítica de ella. Por ello, aunque la imagen-objeto nos trate de engañar al pretender aparecer como totalidad, queriendo borrar los rastros de su trascendencia abstracta, no es en ella donde el principio de la realidad toma sentido; ${ }^{34}$ más bien, es ella un punto de partida desde el cual uno puede acceder a los síntomas, a las contradicciones, a los reflejos ideológicos, a las críticas de una época, etc., considerando que se tomará en cuenta la serie de procesos que la complejizan, en donde "el viaje al pasado es la reelaboración del significante (Slavoj Žižek)".

\footnotetext{
32 "...de modo que la fotografía más insignificante expresa, además de las intenciones explícitas de quien la ha tomado, el sistema de los esquemas de percepción, de pensamiento y de apreciación común a todo un grupo. BOURDIEU, Pierre La fotografía: un arte..., cit., p. 22.

${ }^{33}$ KOSSOY, Boris Fotografía..., cit., p. 83.

${ }^{34}$ Cfr. BAUDRILLARD, Jean Crítica de la economía..., cit., p. 180.
} 
Ubicar la imagen en su contexto, ${ }^{35}$ datarla, revelar o recuperar su intención oculta o manifiesta, consciente e inconsciente, explícita o implícita, situarla en su momento, su lugar o campo propio y de allí derivar su posible significación, su sentido o su mensaje. Lo importante es entender el modo en que se hacen los significantes de la imagen, para posteriormente ir más allá del autor, de sus objetivos, revisar su impacto, sus efectos, sus consecuencias, sus lecturas y sus interpretaciones por parte de sus receptores. Ahora bien, si esto es leer una imagen, ¿qué sería mirarla? Sería intentar entenderla con ayuda de la mente en términos gráficos, pictóricos, visuales, etc.; volver narración una o miles de imágenes fijas o en movimiento, acompasadas, sucesivas, superpuestas, conectadas, contrapuestas, en conflicto o en lucha. La imagen no es solo un objeto, sino un acto, esto es, un algo que hay que descubrir, que nos invita a pensar más allá de lo que aparentemente nos muestra.

Por lo mismo, hacer uso de la historia de la mirada es poder distinguir, entre las posibles significaciones originales y nuestras lecturas, lo que obedece a una práctica histórica de comprensión del contexto, del propósito y del discurso del documento (textual o no) bajo estudio; de suerte que no existe contradicción entre investigar las posibles significaciones originales de las imágenes y, a la vez, plantear preguntas e interpretaciones nuevas que nos permitan introducir nuevos planteamientos históricos del funcionamiento de la realidad misma. ${ }^{36}$

\section{El proceso de recepción. La emisión del mensaje. La denotación y connotación}

¿Las imágenes quieren ser interpretadas? Las imágenes nacen para ser interpretadas. Roland Barthes dice: "cada objeto del mundo puede pasar de una existencia cerrada, muda, a un estado oral, abierto a la apropiación de la sociedad, pues ninguna ley, natural o no, impide hablar de las cosas"37, y mucho menos de la imagen-objeto. Pero ¿cómo conectar la brecha que hay entre el receptor y la imagen-objeto?

Algunas imágenes no "sólo capturan una supuesta realidad como un fragmento de tiempo y espacio, sino que depende de los juicios, ideologías y preferencias de la persona que opera el aparato, de quienes encargan las

\footnotetext{
35 "Fuera de contexto, las unidades icónicas no tienen estatuto y por tanto no pertenecen a un código. Fuera de contexto, los signos icónicos no son signos verdaderamente, como no están codificados ni se asemejan a nada, resulta difícil comprender por qué significan. Y, sin embargo, significan. Así un texto icónico más que algo que depende de un código, es algo que instituye un código". ECO, Umberto Tratado de Semiótica General, Ed. De Bolsillo, México, 2005, p. 316.

${ }^{36}$ THOMPSON, Lanny "La fotografía como documento histórico: la familia proletaria y la vida doméstica en la ciudad de México, 1900-1950", en Revista Historias, INAH, núm. 29, octubremarzo de 1993, p. 109.

${ }^{37}$ BARTHES, Roland Mitologías, Editorial Siglo XXI, México, 2010, p. 200.
} 
imágenes, las reproducen y miran desde diferentes espacios, e incluso en ocasiones desde los propios sujetos que posan". ${ }^{38}$ Ahora bien, nosotros quisiéramos ir un poco más allá y plantear que los juicios, las ideologías y preferencias de los que operan el aparato, así como de los que encargan las imágenes, etc., no son simples y llanas, sino que están inmersas en un mundo complejo, contradictorio y construido sobre dinámicas cotidianas que reproducen y favorecen una práctica material determinada, muchas veces acorde con el discurso dominante.

Parte del interés de este ensayo es especificar el papel que juega el mirar en la comprensión de la creación de la imagen-acto. Como hemos insistido, el mirar no es algo pasivo, sino que implica darle un orden a lo visible; es un modo de organizar la experiencia de aquello que se ve o que se quiere ver por medio de la experiencia cotidiana. La imagen recibe su sentido de la mirada, y la mirada (al igual que la imagen) está inmersa en un mundo práctico en el cual existen estructuras jerarquizadas y asimétricas del mundo social, y como parte de ese mundo se organiza así mismo la experiencia visual práctica en el cómo y qué miramos. Por ello nos atrevemos a decir que no todo es una cuestión de exégesis de la imagen-objeto, hay que encontrar los caminos que nos lleven a entender y cuestionar a la imagen como acto. ${ }^{39}$

El sujeto receptor, sea este social o individual, es un sujeto en situación ${ }^{40}$ que se enfrenta a una imagen que, en el antes, en el ahora y en el después, es, fue y será un objeto en situación, de modo que esta no se encuentra desapegada de ninguno de sus orígenes, pero tampoco está atada a él; es decir, el receptor, interesado en descubrir la abstracción de lo que ve, necesita indagar en las líneas que engloban al significante; significante que le da a la imagen los

\footnotetext{
${ }^{38}$ DOROTINSKY, Deborah "La puesta en escena de un archivo indigenista: el archivo México Indígena del Instituto de Investigaciones Sociales de la UNAM", en Cuicuilco, vol. 14, núm. 41, Escuela Nacional de Antropología e Historia, México, septiembre-diciembre de 2007, p. 44. "Es pues por naturaleza un objeto pragmático, inseparable de su situación referencial. Esto implica que la foto no es necesariamente semejante (mimética) ni a priori significante (portadora de significación en sí misma), aun cuando, por supuesto, los efectos de analogismos y los efectos de sentido, más o menos codificados, acaben interviniendo con frecuencia a posteriori". DUBOIS, Philippe El acto fotográfico. De la representación a la recepción, Ediciones Paidós, Barcelona /Buenos Aires/ México, 1986, p. 91-92.

${ }_{39}$ Como objeto material del contenido es donde la forma social consuma su abstracción y se reproduce como forma. Su magia está allí en la producción de los contenidos y de las conciencias para recibirlos, la cultura se mueve entre la trascendencia de los valores y de las conciencias, discusión errónea y falsa dialéctica, la ideología no está ni de un lado ni de otro, es esta misma y única forma que atraviesa todos los campos de la producción social. Cfr. BAUDRILLARD, Jean Crítica de la economía..., cit., p.169.

${ }^{40}$ La situación refleja la facticidad del sujeto y su libertad. SARTRE, Jean Paul El ser y la nada, Editorial Losada, Buenos Aires, 1998, p. 336.
} 
diferentes sentidos y significados simbólicos desde los cuales puede ser interpretada. ${ }^{41}$

Podríamos decir que una imagen-objeto, como la fotografía, solo tiene un significado para el observador desde sus propios horizontes de sentido, por lo que este tiene que recurrir a elementos externos para poder bosquejar algunos significados. Si los elementos que se encuentran no le permiten acceder al significado de determinada imagen, esta quedará interpretada de manera espontánea. Ahora bien, si el observador tiene conocimiento de los elementos que recrearon el significado de dicha imagen, tendría que pasar a un segundo proceso en el cual pudiera entender el sentido que tuvo o que tendrá la representación que hay en la foto en su contexto histórico.

A pesar de ello, el carácter simbólico podría ser explicado pero no recreado por completo. Para encontrar su significado histórico-social se tendría que buscar en la imagen el código temporal que la rodea, sea este dominante o no, y sobre él, indagar cuál posición fue definida por su creador, cuál por el medio que la hizo circular, o cuál por el estudio del referente fijado en la imagen, o a través de la persona, grupo o institución que encargó la imagen. Por sí solo, lo visual de la imagen no basta para transmitir un conocimiento del acontecer histórico-social, se requiere dar un rodeo al material adicional que la sitúe en un contexto determinado.

El carácter polifacético del significante se da porque este no está dado abiertamente al ser que percibe, cambia continuamente con las transformaciones de la realidad y según se modifican los códigos dominantes. Es por medio del viaje al pasado, por parte del que recibe la imagen y la quiere interpretar, desde donde se elabora nuevamente al significante. De esta manera, ante la necesidad subjetiva del receptor por nombrar de algún modo las imágenes del pasado, este debe aprehender el pasado ("espacio de experiencia") desde las propias experiencias con las que los hombres construyeron su presente ("horizonte de expectativa"), todo ello con el fin de hacer que ese distanciamiento de los tiempos se haga más asequible, y aquello que nos es lejano no se cierre allí donde se procesó, sino que quede proyectado hacia el futuro.

Como se puede ver, la distancia temporal no tiene que volverse, por lo tanto, un obstáculo a superar. Lo importante, en este caso, consiste en ver en la distancia temporal una posibilidad positiva brindada a la comprensión. Nietzche nos recuerda que el presente hace, en cierta medida, al pasado, en tanto nuestra valoración sobre las cosas ocurridas depende de las circunstancias

${ }^{41}$ Cfr. ŽIŽEK, Slavoj El sublime..., cit., pp. 87-124. 
actuales. ${ }^{42}$ Muchos historiadores subrayan tenazmente esta paradoja como la parte maldita de la disciplina de la Historia, como un pecado original estrechamente vinculado a esta, pero continuamente negado por la misma. El hecho es que esta cuestión ha situado la operación de la historiografía sobre un entre-deux: entre lo que una imagen comunicaba en el ayer y lo propio y contemporáneo del receptor. ${ }^{43}$

Así, si es en el proceso de transmisión donde se mediatiza constantemente el presente y el pasado, se podría llegar a decir, entonces, que es en este proceso donde la mirada del receptor queda atada a los parámetros de la imagen y a su configuración visual. Bajo esta perspectiva, el tiempo sería para este solo el tiempo de la imagen, y el papel del que interroga sería el de preguntarse sobre la forma en la que se creó visualmente la imagen. ${ }^{44}$

Lo antes señalado nos permite percibir cómo, poco a poco, la escasa transparencia significativa de las prácticas sociales del pasado, así como la distancia del historiador con estas mismas, lo va apartando de la imagen, del ideal de explicación por medio de leyes y ejemplos, y lo va llevando, cada vez más, hacia el ideal explicativo de casos e interpretaciones. ${ }^{45}$ De esta forma, a través de mirar y de cuestionar las representaciones visuales, se puede afirmar que el receptor -no pasivo- se mueve sobre la misma plataforma que el hermeneuta (digamos aquí, de paso, que esto sucede solo en el mejor de los casos, pues en otros, las interpretaciones animan a pensar a las imágenes como mera ficción, ya que al derrumbarse todo paradigma científico sólo nos quedaría, supuestamente, la libre y arbitraria construcción de discursos).

Así, aparentemente, al no poder captar en su totalidad el lenguaje de lo visual por ser un sujeto situado dentro de un momento histórico particular y con parámetros culturales diferentes al de su objeto de observación, el historiador no podría hacer más que múltiples interpretaciones de

\footnotetext{
${ }^{42}$ Ver: NIETZSCHE, Friedrich Wilhelm Sobre la utilidad y el perjuicio de la historia para la vida (II intempestiva); Edición, traducción y notas de Germán Cano, Biblioteca Nueva, Madrid, 1999.

${ }^{43}$ DOSSE, François "Michel de Certeau et l'écriture de l'histoire", en Vingtième Siècle. Revue d'histoire, Sciences Po University Press, No. 78, apr-jun, 2003, p. 145.

${ }^{44}$ Esta suposición radical, nos llevaría, sin embargo, a cuestionarnos, si es en verdad cierto que, como dice Roland Barthes, las huellas a las que se acerca el historiador no pueden tener otra existencia más que la meramente lingüística. BARTHES, Roland La cámara..., cit., p. 176.

45 “Ciertas verdades sobre las ciencias sociales parecen hoy en día autoevidentes. Una de ellas es que en años recientes ha habido una enorme mezcla de géneros en la ciencia social, así como en la vida intelectual en general, y que tal confusión de clases continúa todavía. Otra es que muchos científicos sociales se han apartado de un ideal de explicación de leyes-y-ejemplos hacia otro ideal de casos-e-interpretaciones, buscando menos la clase de cosas que vincula planetas y péndulos y más la clase de cosas que conecta crisantemos y espadas". GEERTZ, Cliford "Géneros confusos. La reconfiguración del pensamiento social", en American Scholar, vol. 49, núm. 2, primavera de 1980, p. 165.
} 
interpretaciones de las imágenes, ${ }^{46}$ o bien de los discursos narrados por otros intérpretes. De este modo, la idea de una objetividad absoluta se deshace en sus manos y con ello los imperativos de verdad que yacen en los paradigmas epistemológicos de la interpretación histórica.

Este hecho ha conducido a muchos historiadores a deconstruir toda entidad sustancial, o lo que es lo mismo, a desustancializar todo por medio de la interacción de una red de sobredeterminaciones diversas, sin núcleo fijo ni sin significante rígido. En este caso, cada imagen, tanto la producida como la que intenta ser interpretada, estaría inscrita en una serie de materialidades y contingencias que permitirían una infinidad de lecturas y procesos de interpretación. Quien tiene necesidad del lenguaje y de las imágenes, no puede, por lo tanto, sustraerse a la pretensión de esta hermenéutica. ${ }^{47}$ Pero ¿se agotan las condiciones de posibilidad de una interpretación histórico-social en la diversidad de los lenguajes visual de la imagen? ¿O hay condiciones extravisuales o previsuales que permitirían encontrar o articular un punto real en torno al cual las diferentes interpretaciones se conectan? ¿Es posible romper la brecha entre vivencias y visiones del mundo tan diferentes como la del creador, la de la propia imagen y la del receptor?

Por el lado de la imagen, se puede admitir que estas trasmiten un contenido. Si se intenta verbalizarla, en ella se descubren unidades semánticas identificables -una mujer, un niño, un bosque, un animal, un color, una textura, etc.-, y ello es así porque en la imagen se ve plasmado un acto de referencia que permite instituir un pre-código. Por ello pensamos, en primera instancia, que la imagen, a diferencia de las palabras, no puede predicar su no existencia, "las imágenes, tanto si representan objetos existentes como objetos inexistentes o ningún objeto, son siempre afirmativas. Para decir Ceci n'est pas una pipe necesitamos palabras. En cambio las imágenes son lo que son". ${ }^{48}$ De modo que cuando una imagen, por ejemplo, una fotografía, ofrece ante nuestra mirada interrogante la visión de tal o cual personaje, por ejemplo, un hombre viejo de

\footnotetext{
${ }^{46}$ Michel Foucault nos refiere algo al respecto de la soberanía y el poder de los textos. Comenta que en muchas sociedades, la generación de discursos ha sido vigilada, catalogada, seleccionada, organizada y redistribuida con conocimientos muy específicos. Contra ello, lo que se ha intentado es contrarrestar dentro de los mismos textos sus poderes y peligros, es decir, poder lidiar con sus eventualidades, evadir su concretica existencia y resistirse a sus efectos. Así tenemos detrás de todo discurso una serie de poderes que reaccionan unos con otros influyéndose entre sí.

${ }^{47}$ Enmarcados en este contexto, nuestras ideas se juegan ahora en el vasto ámbito del uso de los diferentes materiales que respaldan la memoria histórica. "Naturalmente resulta imposible estudiar el pasado sin la ayuda de toda una cadena de intermediarios, entre ellos no solo los historiadores de épocas pretéritas, sino también los archiveros que ordenaron los documentos, los escribas que los copiaron y los testigos cuyas palabras fueron recogidas". BURKE, Peter Visto y no visto: el uso de la imagen como documento visual, Barcelona, Editorial Crítica, 2001, p. 16. ${ }^{48}$ GINZBURG, Carlo Ojazos de Madera, Ed. Península, Barcelona, 2000, p. 143.
} 
bigote sentado frente a una máquina de coser, vestido de camisa y chaleco, hilando un sombrero... estamos seguros de una cosa: ese hombre, ese sombrero, esas vestimentas, esas máquinas de coser, han existido, han estado efectivamente allí, un día, en esa posición; pero el acto fotográfico la ha transformado en algo más. ${ }^{49}$ Hay una morfología de la imagen.

Ahora bien si centráramos el análisis histórico tan solo en lo que la imagen aparentemente nos presenta, se dejaría de lado la influencia que tiene en la historia la construcción de los procesos sociales y la influencia de estos en el actuar humano. De modo que si plateamos solo a lo visual en sí como punto de partida y de llegada de un estudio sobre la fotografía, quedaría desdibujada la existencia real de los sujetos y su actividad como agentes individuales y colectivos de la propia historia. Pero más allá de lo que la imagen expresa, podemos encontrar una realidad que sobrevive tal y como los hombres la han producido, y por más que lo representativo de una imagen provoque una circunstancia específica y dé pie a una determinada realidad, esto no significa que la complejidad de los procesos sociales e históricos en su conjunto proceda solo de ella misma. ${ }^{50}$

La labor del receptor activo, del historiador, del individuo que quiere interpretar, es la de establecer las redes de comunicación entre los procesos sociales y los procesos que engloban todo lo visual en la conformación de las imágenes. ¿Cómo se puede lograr conectar estos dos procesos que parecen inconexos?

Partamos del hecho de que, como afirma Žižek, "el discurso humano nunca trasmite meramente un mensaje, también afirma auto-reflexivamente el pacto simbólico básico entre los sujetos de la comunicación".${ }^{51}$ En las fotografías hay herencias significantes que se desprenden de ella y hay otras herencias que

\footnotetext{
${ }^{49}$ Jacques Aumont, en su obra La imagen, se cuestiona: ¿para qué se utiliza la imagen? Según el autor, la imagen se crea para ser vista por nosotros. Representa un objeto paradójico de dos dimensiones que se refiere a una realidad de tres dimensiones. Así, las imágenes no solo representan un aplanamiento de la realidad, sino también la segmentación de un momento histórico en el cual se realizó. A continuación, el autor nos advierte que, al observar una imagen, el receptor se ve afectado por un efecto psicológico, al cual llama "doble realidad". La primera realidad se relaciona con la imagen, que se percibe como fragmento de la realidad plana (la cual se puede desplazar y mover); la segunda realidad se relaciona con el hecho de que el ser humano intuye por lógica que la imagen en sí pertenece a un mundo de tres dimensiones y, consecuentemente, es una parte de su mundo. Cfr. AUMONT, Jaques La imagen, Editorial Paidós, Barcelona, 1990.

${ }^{50} \mathrm{Si}$ existen tales presupuestos de la historia que no se agotan en el lenguaje ni son remitidos a textos, entonces la Histórica debería tener, desde el punto de vista epistemológico, un estatus que le impida ser tratada como un subcaso de la hermenéutica. KOSELLECK, Reinhart "Histórica y hermenéutica", en KOSELLECK, Reinhart y GADAMER, Hans-George (Coords.) Historia y hermenéutica, Ediciones Paidós Ibérica, UAB, Barcelona, 1997, p. 69.

${ }^{51}$ ŽIŽEK, Slavoj Cómo leer a Lacan, Paidós Espacios del saber, Buenos Aires, 2013, p. 22.
} 
se vinculan a ella y que están más allá de ella, pero que establecen lazos de comunicación con el otro. Se puede decir incluso que ellas mismas construyen metáforas con los diferentes usos de sus técnicas, variables en el sentido histórico del medio, a pesar de que algunas veces parecen extraer sus signos del caos, aun así trasmiten algo. Ahora bien, lo que conecta a la imagen, como ya dijimos anteriormente, con el mundo circundante es el individuo enfrentado a su realidad social y a su realidad visual formativa, la cual es a su vez enriquecida con la expresión personal del autor que crea un discurso y luego una estética, un estilema (o en el caso del cine, cinemas, como los llamó Pier Paolo Pasolini), dando con ello cuerpo a la imagen. ${ }^{52}$ Es mucho más que una metáfora aislada, ya que ella misma nos refiere al hecho de que hasta para describir el mundo visible en imágenes necesitamos desarrollar un sistema.

Tomemos esto por el lado de la creación. Por el lado de la interpretación, el individuo que la intenta descifrar se enfrenta también a una realidad e historia concreta y posee, igualmente, una concepción del mundo desde sus horizontes de sentido (cognoscentes o no).

Pero el mundo social al que se enfrentan, tanto la imagen en su proceso de circulación como el creador o el intérprete, no está dado de modo único y sustancial, existe en él una amplia cantidad de interpretaciones, o dicho de otro modo, hay una realidad simbólica que es "descifrada" por el individuo, digamos desde su "enfermedad", su posición política, su situación social, etc., y frente a ella toma postura.

Un ejemplo de ello sería la película japonesa Rashomon de Akira Kurosawa, en donde un mismo hecho, la muerte de un samurái, es descrita desde cuatro puntos de vista: el del asesino del samurái, el de la esposa de este, el del leñador que fue testigo y el del propio asesinado -el cual habla a través de un médium-. Así contada, pareciera que la historia nunca toca una verdadera aproximación a los hechos que se describen; lo único cierto es que ninguna versión coincide. Entonces, ¿nunca se podrá alcanzar la verdad del hecho porque es imposible trascender el nivel de las subjetividades de cada narración? Planteadas así las cosas, sería muy difícil responder afirmativamente a esta cuestión, ya que el punto no es ése; el planteamiento es entender cómo se construye la realidad para que existan determinadas visiones tan distantes una de otra. Lo que sorprende del filme es que nos muestra cómo cada versión depende de la posición social e ideológica que cada personaje tiene con su mundo circundante o con la realidad. Incluso nosotros mismos podemos manifestar simpatías por una u otra forma de mirar las cosas, por la forma de ver de la mujer violada que se enfrenta al juicio de una sociedad patriarcal, el

${ }^{2}$ DELEUZE, Gilles La imagen-movimiento. Estudios sobre cine 1, Editorial Paidós Comunicación, Barcelona, 1984, p. 200. 
cinismo del criminal que se burla de todas las formas sociales ${ }^{53}$ y que no respeta nada, el del "valiente" y poderoso samurái que defendiendo su honor es traicionado por el asocial que lo acecha como un animal, o por el magnífico desenlace al que nos lanza el leñador.

Pero la unidad está dada por un hecho traumático, es decir, este mundo no está conformado por una armonía plena donde el individuo se desarrolle libremente y sin más interpreta; es más bien un mundo inadecuado, que no está construido para satisfacer las necesidades sociales e individuales en su totalidad, sea porque en términos económicos se imponga la ley del valor, en términos familiares la ley del padre, en términos sociales las estructuras jerarquizadas de la sociedad, en términos políticos las diferentes estructuras de poder, o por la interacción de todos estos elementos y de otros más. Esta es la construcción no escrita de la sociedad, el "orden simbólico", "el Gran Otro"; es la segunda naturaleza de todo ser hablante: es el agua donde nado, la cual nunca puedo poner frente a mí y aprehender, pero que nos impone qué hacer y cómo movernos. Para enfrentarse a está inadecuación, el ser humano tiene que tomar una postura que le permita vivir. Dicha postura puede concordar con la ideología dominante y encerrar al individuo en una burbuja ideológica que, de alguna manera, le hace olvidar, por cierto tiempo, el enfrentamiento y las contradicciones sociales, funcionalizando su experiencia dentro del orden social imperante.

Así, como cada narración parece en último término contingente, una manera en que la experiencia de la realidad histórica determinada puede lograr su unidad, es encontrando el elemento significante que mantienen cohesionada la forma social imperante -o el edificio ideológico, o la estructura jerárquica, etc.-, y que se define por su identidad relacional y no por el contenido real de la narración. El modo en que la vivimos está siempre mediado por diferentes modos de simbolización, así que no es el objeto real el que nos garantiza el punto referencial, la unidad o la identidad de determinada experiencia histórica; al contrario, es la referencia a un significante relacional (ser una mujer, sometida o revolucionaria, en un mundo patriarcal; ser un excluido social en una sociedad jerarquizada, etc.) lo que confiere unidad e identidad a la experiencia con la realidad histórica. La labor del historiador es captar estos diferentes modos de simbolización de la realidad y su relación arbitraria y traumática con el significante unitario, así como entender cómo se construye el significante unitario en su relación con los diferentes modos en que la realidad

\footnotetext{
${ }^{53}$ Incluso la forma en que filma Kurosawa la escena donde aparece por primera vez el asesino, es grabada de modo que se pueda apreciar el carácter casi animal del personaje. La cámara se mueve, en congruencia con el argumento presentado por el director, de tal forma que el personaje surge como una presencia salvaje que acosa con su mirada a la "pacífica" pareja que camina por el bosque.
} 
se simboliza. ${ }^{54}$

Podríamos entonces esbozar una primera unidad entre el creador, el referente, la imagen y el que interpreta, y es que en todos podemos hallar una relación con el corazón mismo de los procesos contradictorios que forman lo social y lo individual en un contexto histórico de un mirar determinado; y es a causa de esta relación que cada uno puede tener efecto significativo, ya sea que este esté guiado bajo la ley del código dominante, bajo el control de los sentidos, o bien desde la crítica al código dominante, desde la arbitrariedad del referente, desde el cultivo dialéctico o autocrítico de su identidad, etc.

La otra complejidad derivada de la imagen, al ser pensada desde su versión estética, está estrechamente ligada al hecho que Bolívar Echeverría señala en su libro Definición de la cultura, en el cual toma importancia la irrupción que tiene lugar, en el mundo del arte, el plano imaginario, ${ }^{55}$ que es, en primera instancia, una existencia "en ruptura" o una infiltración del comportamiento extraordinario dentro del comportamiento cotidiano; "esto es, en el plano en el que la semiosis lingüística ejerce de manera inmediata su dominio sobre la semiosis práctica, en el que las significaciones atadas se liberan de sus ataduras, se convierten en simulacros de sí mismas, haciendo como si pudieran desenvolverse en un juego libre, con independencia del substrato al que dan forma, del contacto que las posibilita". ${ }^{56}$

En los señalamientos que anteriormente hemos hecho sobre la historia crítica de la mirada, la imagen-acto queda vinculada a su dimensión y función socio-histórica. En este nivel, ella misma, y las sub-codificaciones que de ella se desprendan, se encuentran en "automático" en el grado mínimo de su cultivo. ${ }^{57}$ Por ello es importante tomar en cuenta a la imagen-acto siempre más allá de la mirada meramente contemplativa, más allá de sus "ataduras" sociales. Y es que si ella está en relación a un mirar artístico, tendría que ser considerada en sus múltiples representaciones de su ser artístico; es decir, se tendrían que entender los momentos de ruptura que el creador tuvo que llevar a cabo para lograr cultivar críticamente su mundo cotidiano.

\footnotetext{
${ }^{54}$ El paso crucial en el análisis de un edificio ideológico es, detectar tras el deslumbrante esplendor del elemento que lo sostiene unido ("Dios", "País", "Partido", "Clase"...) esta operación auto-referencial, tautológica, representativa, es decir el elemento a través del cual el no sentido del significante irrumpe en pleno significado, se percibe como un punto que da significado a todos los demás y totaliza así el campo del significado ideológico, la democracia es lo que dicen los liberales, se vive como una especie de garantía trascendente, la falta la cubre esa definición con un cierto "error de perspectiva. Ver: ŽIŽEK, Slavoj El sublime..., cit., p. 140.

${ }^{55}$ ECHEVERRÍA, Bolívar Definición de la cultura, Editorial Ítaca-UNAM, México, 2001, p. 191.

${ }^{56}$ ECHEVERRÍA, Bolívar Definición..., cit., pp. 191-192.

${ }^{57}$ ECHEVERRÍA, Bolívar Definición..., cit., p. 192.
} 
Siguiendo con el argumento de Bolívar Echeverría, el proceso de ruptura es un hecho "inofensivo", de consecuencias "puramente mentales", donde los elementos que vinculan al creador con los procesos cotidianos son puestos en crisis momentáneamente.

"La vida cotidiana contiene en su transcurrir una infinidad de momentos, unos mínimos otros mayores, de ruptura lúdica de la rutina. Todos ellos son momentos de crisis y recomposición imaginaria de la incuestionabilidad de todas las leyes naturales $\mathrm{y}$, por tanto, también de aquellas artificiales que, dándose por naturales, sostienen, para bien y para mal, el edificio social establecido." 58

Hay una segunda particularidad dentro de la experiencia estética en la que el creador, ubicado en una situación histórica determinada, se traslada al escenario de lo imaginario. En dicho escenario está presente siempre un abismo en el que la imaginación aparece, en un primer momento, separada de lo real, para retornar, en un segundo momento, al escenario de la "conciencia objetiva" a la cual se llega a través del uso de dispositivos especiales en los que se concentra el oficio del artista. Para el caso de las imágenes, usa el lenguaje y las diferentes técnicas visuales como medio de comunicación, como medio expresión de su pensamiento visual y como forma de crear su práctica visual. Con ello proporciona a la comunidad oportunidades de experiencias estéticas. Lo imaginario retoma de las experiencias que el artista vive, como momentos extraordinarios, aquello que en el mundo real es producido por la festividad humana o por la crítica a las vivencias cotidianas de cada creador en un tiempo y espacio determinado; de allí toma el material necesario para que dichas experiencias queden mimetizadas en objetos estéticos.

Volviendo al ejemplo de la película Rashomon, la ruptura estética de la vida social dentro de su filme, queda enmarcada en la estetización espontanea que hace del comportamiento cotidiano, reflexivo y subjetivo de cada uno de los personajes, creando el drama escénico en que se juega la historia del juicio llevado a cabo para resolver el asesinato de un samurái. La simbolización espacial en la que se desenvuelve el arte cinematográfico de este filme de Kurosawa nos permite interpretarla y captar, desde el plano imaginario realizado por la técnica artística, la ruptura con la vida cotidiana con la vida social al estetizar, de manera tan sorprendente, las dificultades que tiene el hombre para alcanzar la verdad. ${ }^{59}$

${ }^{58}$ ECHEVERRÍA, Bolívar Definición..., cit., p. 202.

59 "La técnica más importante que Kurosawa emplea para ayudar a la yuxtaposición narrativa es el encuadre, es decir, la manera de enmarcar a los personajes y el espacio. La puesta en escena y la manera en que los actores se vinculan con el otro y con su entorno inculcan un 
Cuando el creador retorna a la comunidad social con el desarrollo de algo que traslada de la plenitud imaginaria de la vida al mundo terrenal de la experiencia, es decir, al estar presente la creación estética en la imagen-acto, esta retorna al mundo social cotidiano no solo para ser una presencia vacía; su retorno -cuando es rupturista- será para transformarlo, si no a plenitud, sí modificando el disfrute de los receptores, potenciando, cultivando o provocando rupturas y nuevos ciclos autocríticos en las prácticas cotidianas o rutinarias. El significado de este filme está en relación directa con quién lo interroga $u$ observa, y es este quién vehicula, en dicho sentido, los aportes hechos por el autor. Lo mismo pasa al transitar de la imagen-objeto a la imagen como acto.

\section{La búsqueda de las imágenes-acto}

En este escrito nos hemos aproximado, desde una perspectiva crítica, a establecer ciertas bases teóricas para el estudio de la historia de la mirada. En él se ha puesto como fundamento epistemológico básico el reconocimiento de que lo real-histórico y la realidad concreta funcionan, en gran medida, bajo un mundo rodeado de apariencias, bajo realidades que surgen de forma enigmática mostrando verdades sospechosas, por lo que la obtención del conocimiento que aquí proponemos tiene que tomar en cuenta varios criterios que resumiremos a continuación.

Lo primero que se ha considerado es que en la constitución del mundo social humano se borran del recuerdo los hechos que dan cuenta que este mundo está organizado continuamente en estrecha empatía con los grupos y con las formas sociales que controlan el poder en sus diferentes dimensiones. $\mathrm{O}$ como Walter Benjamin diría, que los que han resultado victoriosos a lo largo de la historia son los que verdaderamente han estado interesados en ocultar y presentar, de forma espontánea, inconsciente o a su conveniencia los datos que le son incómodos.

Ligado a lo anterior, señalamos que la contingencia propia de la vida moderna obliga o vuelve indispensable el ocultamiento del funcionamiento de la realidad para que en la práctica permanezcan vigentes las formas institucionalizadas de la sociedad. En este sentido, las prácticas ideológicas y el discurso dominante operan en la vida cotidiana, no solo como falsa conciencia, sino reproduciendo y actualizando las diferentes formas de poder en que se

sentido de subjetividad en la audiencia, así como la cámara es una especie de extensión de las perspectivas individuales de los personajes que le permiten al espectador adentrarse y dejarse llevar por las respectivas versiones de los hechos". NERDISTA, Videoensayo How Akira Kurosawa Framed Rashômon, editado en: http://enfilme.com/notas-del-dia/video-la-importanciadel-encuadre-en-rashomon-de-akira-kurosawa-un-videoensayo, 2013. 
desarrolla el dominio en la sociedad moderna. El "ocultamiento" permite neutralizar momentáneamente las contradicciones sociales y, gracias a ello, la sociedad puede funcionar y legitimar sus prácticas como esencias de un comportamiento natural.

En tercer lugar, se ha tomado en cuenta también el elemento propio de la contingencia humana, en cuyo funcionamiento se encuentra la inadecuación del hombre frente al mundo social, su enfrentamiento a un vacío o a una nada que le dé una estructura sustancial. Ante esta situación, el hombre responde de maneras muy diversas según se construyan sus experiencias y horizontes de sentido. Muchas veces, lo que encontramos en estas experiencias de sentido es un ocultamiento que la sociedad debe hacer de su propia fatalidad humana y del enfrentamiento al mundo de la vida. Y se dice ocultamiento, porque al no ser las contradicciones meramente naturales sino principalmente productos sociales, se tiene que organizar de tal modo la reproducción social para que estas no sean perceptibles. Por ello resulta indispensable, para la vigencia práctica de las instituciones dominantes, una construcción ideológica. Solo gracias a que esta esconde el hecho de que no somos naturalmente así, las formas de dominio pueden legitimarse como naturales.

Una vez considerados los criterios anteriores veremos que la obtención del conocimiento que proponemos, desde la historia crítica de la mirada, tiene que estar atento e ir a contrapelo de las aparentes luminosidades que construye el discurso dominante, fijar las miradas en los procesos contradictorios generados por la vida moderna, así como entender las diversas respuestas que el ser humano tiene ante la contingencia de su vida. El historiador, en ese sentido, tendría que ejercer no solo una mirada simple de sus fuentes, sino entender críticamente que "la realidad histórica es efectivamente enigmática y sus verdades evidentes son siempre sospechosas, porque la constitución misma de lo humano está ocultando algo inconfesable, que solo sale a la luz, a pesar suyo, en los puntos fallidos de sus obras" ${ }^{60}$

De modo que, si la historia avanza bajo el supuesto de una legitimidad natural de la injusticia, de las jerarquías sociales, de la represión y el dominio de una parte de la sociedad hacia otra, el procedimiento que el historiador crítico tendría que ser capaz de descubrir o revelar es aquel que nos indique que determinados datos están allí para engañar.

El ejercicio del mirar crítico tiene que reconocer, entonces, que no es la imagen en sí, como tampoco el texto en cuanto tal, el que nos permite acceder al estudio histórico-social; al revés, son aquellas imágenes, aquellos documentos los que, por su carácter sintomático, nos conducen a sospechar de las

${ }^{60}$ ECHEVERRÍA, Bolívar "La historia como descubrimiento", en Contrahistorias. La otra mirada de Clío, México, núm. 1, septiembre 2003- febrero 2004, p.32. p. 29-34. 
intenciones obstructoras de una realidad aparente: en los lapsus que se le escapan, en aquellos puntos que dejan ver las inadvertidas contradicciones sociales. ${ }^{61}$ Consideradas de este modo, las imágenes y los documentos dejarían de ser simples piezas de estructuras que necesitan ser completadas, para convertirse en huellas que nos muestren los actos fallidos, las cicatrices, los moretones, los traumatismos que no son vistos a simple vista y que están escondidos por la realidad que se nos presenta, es decir, "son indicios de que todo aquello que aparece en él como un documento de cultura es al mismo tiempo un documento de barbarie". ${ }^{62}$

Žižek lo diría de otro modo, que el retorno de lo reprimido le viene al historiador desde el futuro, es decir, de aquel síntoma que le hace observar de manera diferente el pasado que se mira. El receptor, en este caso el historiador, debe indagar en lo que ha sido reprimido por la realidad, pero que arbitrariamente aparece en otro momento como algo que permite captar por un instante las contradicciones en que se funda dicha realidad. ${ }^{63}$ Puede ser incluso que una imagen o un documento se muestren bajo la figura de un destello luminoso, pero hay que advertir que este destello no será otra cosa que una prueba enceguecedora que pretende ocultar su lado oscuro. Su aparente luminosidad, interna o externa, está lejos de ser real.

¿Por qué, entonces, la realidad aparece en ciertos documentos ocultándose y reprimiéndose así misma? Porque ella misma ha sido creada por el ser humano que habita $y$ vive en un mundo lleno de conflictos $y$ contradicciones, donde la armonía y la libertad plenas no existen y, por lo tanto, tampoco la prueba plena. De este hecho se deriva también que de ella se extraen múltiples interpretaciones, es decir, que ante la incertidumbre que provocan los múltiples significados subjetivos de un hecho, generados en parte porque hay una red rota de comunicación entre lo creado por el ser humano, la realidad y el ser que la interroga, el gesto necesario -pensado desde el posestructuralismonos deja ante una única alternativa: la de evidenciar, tras la sólida congruencia de un documento, una interacción de sobredeterminaciones simbólicas, capaces de disolver toda identidad sustancial y colocar a la realidad en una red de relaciones no sustanciales y/o diferenciales. ${ }^{64} ¿$ Cuál sería entonces el contrapunto que este texto propone a dicha perspectiva?

El carácter contradictorio bajo el que se construye el mundo social está siempre oculto para que las estructuras sociales continúen funcionando de

${ }^{61}$ Cfr. ECHEVERRÍA, Bolívar “La historia...", cit., p. 29-34. Cfr. GINZBURG, Carlo Tentativas, Facultad de Historia de la Universidad Michoacana, Morelia, 2003.

${ }^{62}$ ECHEVERRÍA, Bolívar “La historia...", cit., p. 30.

${ }^{63}$ Cfr. ŽIŽEK, Slavoj El sublime..., cit., p. 87-124. Ver: KOSELLECK, Reinhart Futuro pasado. Para una semántica de los tiempos históricos, Paidós, Barcelona, 1993, pp. 337-338.

${ }^{64}$ Cfr. ŽIŽEK, Slavoj El sublime..., cit., p. 87-124. 
manera "normal" y constantemente, tanto en la construcción simbólica del plano individual como en la que se refiere al plano social, por lo que el carácter de la realidad polisémica y huidiza es constantemente reprimida, reprimido bajo movimientos ideológicos o aparentes, bajo el discurso dominante o por las pruebas creadas por los que han salido vencedores de la historia. Sin embargo, estas contradicciones sociales no se pueden mantener neutralizadas permanentemente. En algún punto del presente hay un retorno de lo reprimido que se expresa con el constante estallido de las contradicciones sociales, las cuales indican que algo no ha sido resuelto en el pasado. Es esto lo que nos permite realizar la asociación entre el conflicto reprimido y su retorno en la explosión de la contradicción. Este hecho es el que incita al historiador a la búsqueda de los documentos que muestran los actos fallidos, los gestos sintomáticos o las luminosidades que intentan engañarnos, pero que pueden ser indicios de lo que en términos prácticos el discurso dominante, las ideologías imperantes, la diferentes formas de dominio, etc., intentaron ocultar. La búsqueda de la imagen-acto sería entonces aquella que nos permita establecer una cita con el pasado para resolver un conflicto irresuelto del presente.

“...[al hecho de que] el enemigo de la abolición del dominio de una parte de la sociedad sobre el resto de ella es un enemigo que no cesa de triunfar, al hecho de que la necesidad de actualizar el pasado resulta de la experiencia que la sociedad tiene de este fracaso perenne, se debe el que esa actualidad adopte la forma de una exigencia "mesiánica" o de redención del pasado sobre el presente o, lo que es lo mismo, de una capacidad redentora del presente hacia el pasado". ${ }^{65}$

Finalmente, habría que considerar el momento autocrítico de la vida cotidiana formulado desde la estética. Aquí la prueba que se crea -la imagen, el texto, diferentes formas de expresión visual, etc.- funciona como un acto que se dona a sí mismo para producir conciencias, para producir nuevos discursos críticos. Su carácter de prueba le viene de una crítica a las condiciones imperantes de dominio e incita a buscar algo más allá de sí misma, algo que estaba allí, pero que ha sido reprimido por el funcionamiento acrítico de las sociedades modernas.

${ }^{65}$ ECHEVERRÍA, Bolívar “La historia...”, cit., p. 30. 